\title{
A Modern Perspective on Vaccinating Healthcare Service Providers in India: A Narrative Review
}

\author{
Mallavalli Surendranath · Ravi Wankhedkar · Jayesh Lele · \\ Otavio Cintra $\cdot$ Shafi Kolhapure $\cdot$ Ashish Agrawal $\cdot$ Pavitra Dewda
}

Received: September 21, 2021 / Accepted: October 21, 2021 / Published online: November 13, 2021

(C) The Author(s) 2021

\begin{abstract}
Healthcare providers (HCPs) are at increased risk of acquisition and transmission of infectious disease. Vaccinating HCPs is an essential preventive measure to protect them and their patients against communicable diseases, while positively and directly impacting the functioning of the healthcare system. In India, healthcare represents one of the largest employment sectors with 3.8 million HCPs; however, there is limited awareness of national immunisation
\end{abstract}

M. Surendranath

Department of Pediatrics, Vijay Marie Hospital,

Hyderabad, India

R. Wankhedkar

World Medical Association and Sitaram Hospital, Dhule, India

J. Lele

National Hospital Board of India, Mumbai, India

O. Cintra

Medical Affairs, GSK, São Paulo, Brazil

S. Kolhapure · P. Dewda

Medical Affairs, GSK, Mumbai, India

A. Agrawal

Medical Affairs, GSK, Hyderabad, India

P. Dewda $(\bowtie)$

Vaccines Medical, No 252, Dr Annie Besant Rd, Worli Shivaji Nagar, Worli, Mumbai 400018,

Maharashtra, India

e-mail: pavitra.r.deeywadaa@gsk.com guidelines for the Indian HCP population. Data from communicable disease outbreaks across India suggest inadequate vaccination rates amongst HCPs; studies have reported influenza and varicella vaccination rates as low as $4.4 \%$ and $16 \%$, respectively. In this review, we discuss data highlighting the impact of insufficient vaccination coverage, barriers to vaccination, and the lack of immunisation guidelines amongst HCPs in India. COVID-19 vaccination programmes for HCPs have been critical in slowing the pandemic in India. This provides an opportunity to raise awareness about the importance of vaccines amongst HCPs in India.

Keywords: Healthcare providers; India; Recommendations; Vaccination 


\section{Key Summary Points}

Healthcare providers (HCPs) are the frontline workforce tackling infectious and vaccine-preventable diseases (VPDs)

With limited awareness regarding immunisation guidelines amongst HCPs in India, vaccination coverage is low

This can have a significant impact on the health of HCPs and patients, placing an unnecessary burden on the healthcare system

There are several barriers to vaccination uptake in HCPs, including a lack of awareness regarding the risk of VPDs and available vaccines

With effective education and implementation of immunisation programmes, vaccine uptake may increase amongst HCPs

\section{INTRODUCTION}

Healthcare providers (HCPs) are a diverse group of professionals, including physicians, nurses, emergency medical personnel, dental professionals, students, laboratory technicians, pharmacists, hospital volunteers, hospital administrative staff and others. HCPs can be defined as "all paid and unpaid persons working in healthcare settings who have the potential for exposure to patients and/or to infectious materials, including body substances, contaminated medical supplies and equipment, contaminated environmental surfaces, or contaminated air" [1]. They form the backbone of healthcare services and are responsible for the consistent functioning of various facilities. Therefore, HCPs must be protected against adverse health-related conditions that may result from their work, where they are regularly exposed to communicable and non-communicable diseases [2].
Communicable diseases and related adverse health outcomes are a concern for HCPs and their patients. Face-to-face visits allow HCPs to provide invaluable healthcare services to the patient; however, they are at increased risk of communicable disease [2]. For example, transmission of the influenza virus can occur from HCPs to patients and from patients to HCPs [3]. The significance of possible transmission is exacerbated in at-risk populations, including those who are pregnant, immunocompromised or have comorbidities [4]. In the event of nosocomial disease outbreaks in the healthcare setting, control measures can include closure of medical departments, but this is a costly measure. One analysis from August 2005 investigated global outbreaks reported at www. outbreak-database.com and showed that 38.5\% of influenza outbreaks resulted in closure of hospital units in an attempt to reduce the spread of the disease [5]. An additional burden on healthcare services is the transmission of infections from HCPs to family members, which has been observed in the recent COVID-19 pandemic [6]. Initial reports from a Wuhan hospital during the COVID-19 pandemic revealed that $29 \%$ of the cases were HCPs infected with SARS-CoV-2 while treating patients. Of these, $77.5 \%$ worked on general wards, $17.5 \%$ were from the emergency department and 5\% were from intensive care units [7]. Healthcare services risk being understaffed if HCPs are unable to work when infected [8]. This highlights that more cost-effective, protective measures against infectious diseases are needed for HCPs. HCP health and wellbeing is a key consideration in the context of infectious diseases and can be achieved through preventative measures, including telemedicine and vaccination. Initiatives that incorporate vaccination against vaccine-preventable diseases (VPDs) may prevent the transmission and/or acquisition of infections in HCPs [8].

In India, healthcare represents one of the largest employment sectors; however, many HCPs are not routinely vaccinated against VPDs and, due to various barriers, increasing immunisation coverage is a challenge. The COVID-19 pandemic has highlighted the need for better healthcare and disease prevention, especially 
amongst HCPs. The successful rollout of COVID-19 vaccination programmes amongst HCPs has been critical in slowing the pandemic not only in India but also around the world and will probably positively influence the attitudes and perceptions that HCPs have towards vaccinations in general. This provides an opportunity to raise awareness about the importance of vaccinating against VPDs and the need for routine immunisation programmes amongst HCPs in India. In this article we review the current data highlighting the impact of insufficient vaccination coverage and provide recommendations for increasing vaccine uptake amongst HCPs in India.

\section{SEARCH STRATEGY AND SELECTION CRITERIA}

Literature searches were performed using PubMed, Embase and Google Scholar. Search terms were: (hepatitis B AND healthcare providers AND India AND "last 10 years"[PDat]); (India; health personnel; influenza, human); (Mumps OR Rubella OR Measles OR Varicella OR chicken pox AND health care workers AND India); health personnel; tuberculosis; India. Additional searches were performed for COVID19, hepatitis A, meningococcal, diphtheria, pertussis and tetanus vaccinations among HCPs in India. Abstracts and articles were reviewed and relevant data extracted to give the final list of references used. Limitations of this review: the literature search was not systemically designed and the VPDs covered were based on their incidence or impact within the Indian HCP population and may not be all inclusive. This article is based on previously conducted studies and does not contain any new studies with human participants or animals performed by any of the authors.

\section{INDIA'S HEALTHCARE SYSTEM}

The Indian healthcare industry is one of the largest sectors in the country with respect to employment and revenue [9]. Moreover, India is becoming a hub of medical tourism due to the reduced cost and the easy access of healthcare services compared with other countries [10].

India's healthcare system consists of the traditional and modern healthcare systems. Ayurveda, Unani, Siddha and Homeopathy (AYUSH) is the traditional system, which is governed by the Central Council for Indian Medicine (CCIM). The modern system is regulated by the National Medical Commission, replacing the Medical Council of India [11, 12]. The number of CCIM and National Medical Commission colleges in India are shown in Fig. 1 and there were an estimated 3.8 million HCPs in India as of January 2016 [13]. Such a large workforce that cares for the Indian population of 1.33 billion must be protected against acquisition and transmission of infectious diseases while caring for patients [11].

Healthcare in India is further divided into public and private sectors. Usually, the private sector is well equipped with up-to-date technology and modern facilities. However, affordability is a barrier that limits access, with many people in India having low socio-economic status. Overcrowding can occur in both sectors, but is a particular risk in the public sector, which offers most of its services at no cost or comparatively low costs [14]. Overcrowding is an additional risk for the spread of infections and VPDs among HCPs, patients and their visitors, where general wards, waiting halls and emergency departments are often poorly ventilated. To improve our understanding of this risk, we review existing seroprevalence studies to assess the vulnerability of HCPs to infectious diseases.

\section{VPDS AND THEIR IMPACT ON HCPS ACROSS INDIA}

India boasts the largest immunisation programme in the world, vaccinating an estimated 26.7 million infants and 30 million pregnant women per year; however, increasing immunisation coverage is still a challenge. In 2016, an estimated $38 \%$ of children did not receive all basic vaccines in their first year; low uptake in isolated or poorly informed communities and fears of adverse events continue to contribute to 


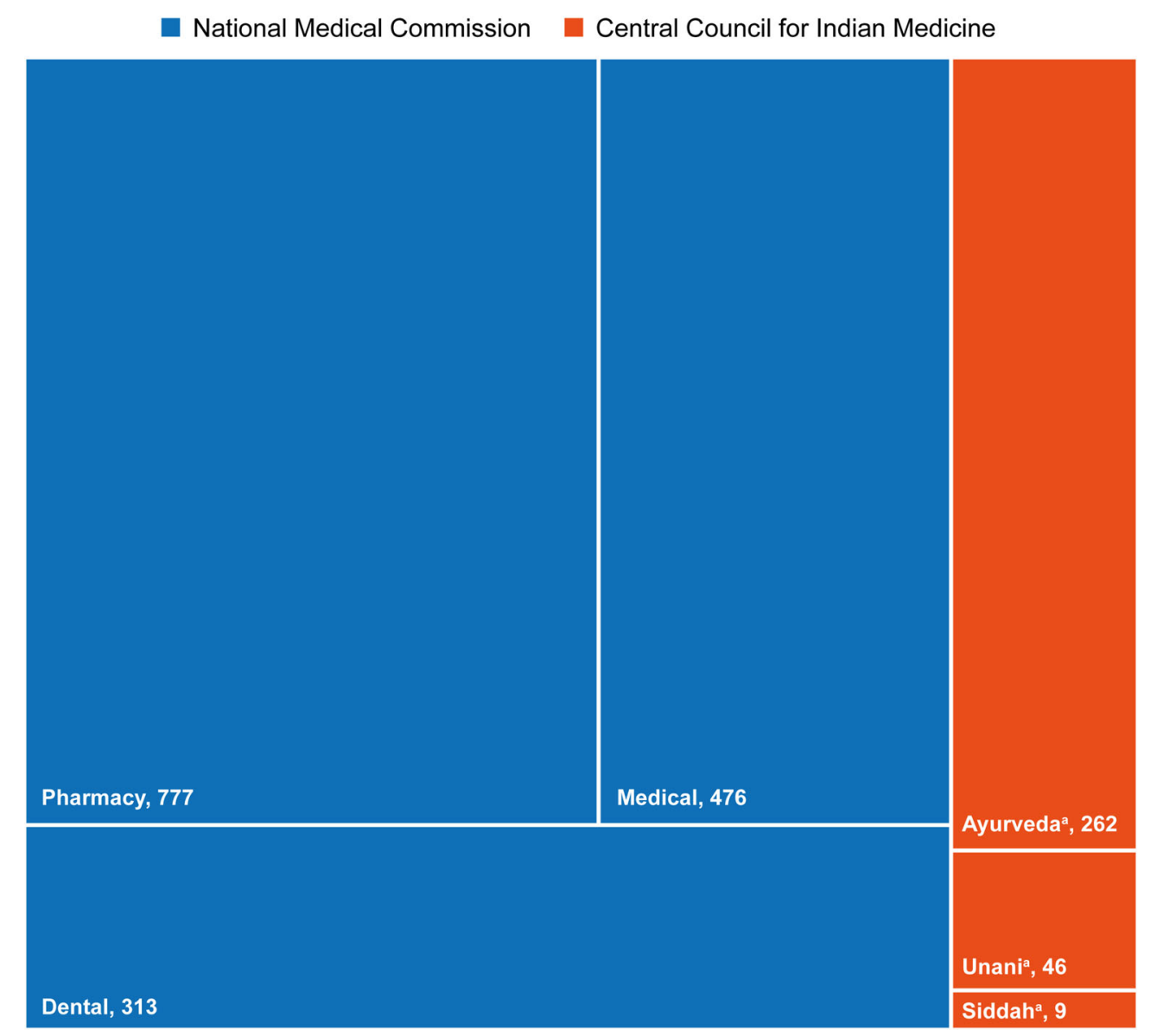

Fig. 1 Number of Central Council for Indian Medicine and National Medical Commission colleges in India. ${ }^{a}$ As of 2014. Remaining data are as of 2017. Source: Central Council of Indian Medicine 2014 estimates https://www. ccimindia.org/index.php. Accessed September 2021. 2017

low vaccination coverage [15]. HCPs can also have poor uptake of vaccinations, with influenza vaccine coverage as low as $4.4 \%$ in one study [16]. Unfortunately, this low uptake (Fig. 2) can have a significant impact on the health of HCPs and patients, as discussed in the following sections.

\section{Measles, Mumps and Rubella}

In adults, measles infection may lead to complications such as hepatic and renal impairment $[17,18]$, mumps infection may lead to complications like orchitis, acute demyelinating
Estimates of Central Bureau of Health Intelligence and National Health Profile 2018. http://www.cbhidghs.nic. in/WriteReadData/1892s/Before\%20Chapter1.pdf. Accessed September 2021. The National Medical Commission has now replaced the Medical Council of India

encephalomyelitis and meningoencephalitis, and rubella infection can lead to severe arthralgia in adults or congenital defects in the foetus in young pregnant women [19].

Several studies have investigated HCP susceptibility to measles, mumps and rubella in India. A cross-sectional study assessing the serological status among medical, dental and nursing students at Manipal University in Karnataka State, South India, revealed that 9.5\%, $32.0 \%$ and $16.6 \%$ of students were susceptible to measles, mumps and rubella, respectively [19]. An investigation into a measles outbreak at a college in Pune, India, found that 23\% (7/31) of medical students tested positive for the 


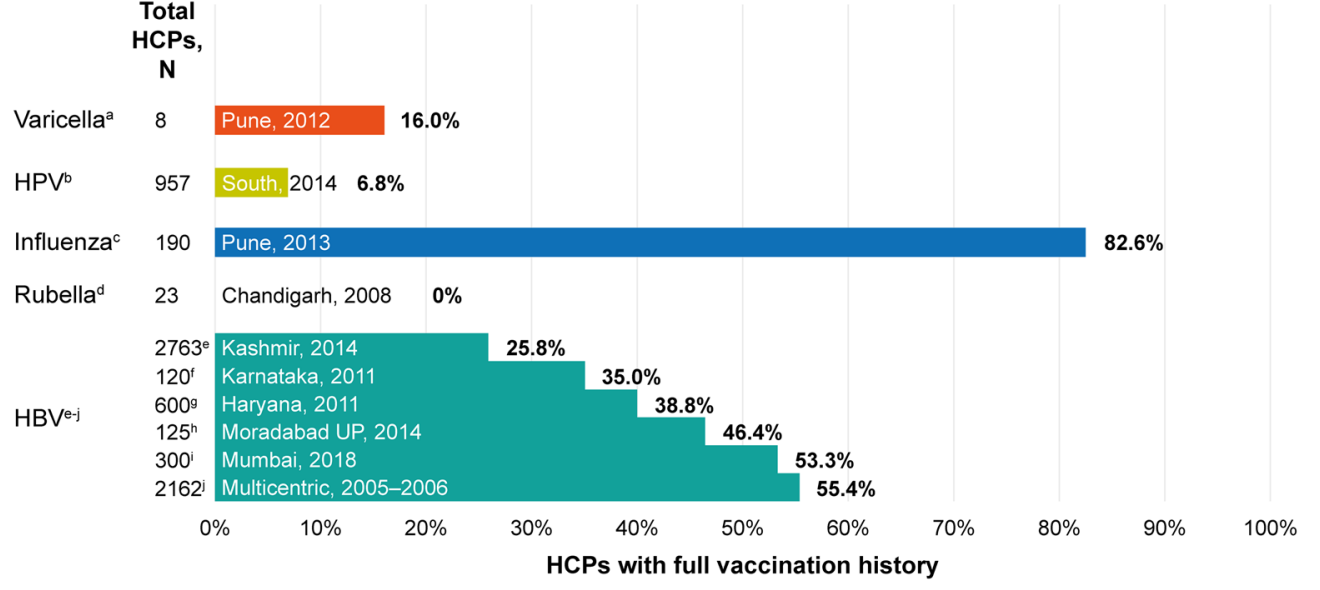

Fig. 2 HCPs receiving vaccines across centres in India. ${ }^{a}$ Bhatti VK, et al. Med J Armed Forces India 2014;70:220-4; ' Swarnapriya K, et al. Asian Pac J Cancer Prev 2015;16:8473-7; ' Pandey S, et al. Indian J Med Res 2013;137:388-90; d'Singh MP, et al. J Med Virol 2010;82:341-4; 'Anjum FB, et al. Int J Med Res Health Sci 2016;5:115-20; ${ }^{\mathrm{f}}$ Phukan P, et al. Int J Occup Environ

measles immunoglobulin (Ig)M antibody, 65\% (20/31) had a history of contact with confirmed measles cases and 100\% had an unknown measles vaccination status [20].

Other studies from India have reported rubella outbreaks in medical colleges among medical students, nursing students and other healthcare staff. In Chandigarh, 23 cases of rubella were reported among medical students, nurses and administrative staff in a healthcare centre in May and June 2008; no one had been vaccinated against rubella [21]. In a follow-up analysis at the same institute assessing the rubella serological status of HCPs and the need for vaccination, $15.3 \%(48 / 313)$ of HCPs were seronegative $(<10 \mathrm{IU} / \mathrm{ml})$ for antibodies against the rubella virus and therefore susceptible to rubella infection. Of those seronegative HCPs, $60.4 \%(29 / 48)$ had a history of contact with pregnant women in their workplace [22]. Similarly, a study conducted in Jodhpur among female medical and nursing students found that $14.4 \%$ were seronegative for rubella antibodies with no history of vaccination in childhood or adolescence [23], and a study of HCPs in Madurai found that $11.4 \%(66 / 581)$ of HCPs were seronegative for rubella $\operatorname{IgG}$ and $\operatorname{IgM}$
Med 2014;4:40-50; ${ }^{\text {P}}$ Pathak R, et al. Int J Med Public Health 2013;3:55-9; ${ }^{\text {h}}$ Kumar S, et al. International J Sci Study 2014;1:43-6; i Dev K, et al. J Assoc Physicians India 2018;66:27-30; 'Sukriti, et al. J Gastroenterol Hepatol 2008;23:1710-5. HBV, hepatitis B virus; HCP, healthcare provider; HPV, human papillomavirus

antibodies [24]. Additionally, in a seroepidemiological study of women in Amritsar, 20\% of women who were HCPs were seronegative for rubella IgG antibodies; these HCPs had no history of immunisation against rubella [25]. A multicentre study conducted in several hospitals across the Tamil Nadu districts of India investigating the serological status of female staff reported that $15 \%$ of female HCPs were seronegative for IgG antibodies against rubella [26].

\section{Varicella}

Varicella may lead to severe complications in adults, including neurological complications, viral and bacterial pneumonia, septicaemia and osteomyelitis. Pneumonia complications associated with varicella infections occur more frequently in adults compared with children [27].

Country-specific susceptibility to varicella infection among HCPs can range from 5 to $50 \%$ [28]. In a study carried out in Mumbai, 28\% of nurses were found to be seronegative for antibodies against the varicella zoster virus [29], and in another study, varicella susceptibility among medical, dental and nursing students was found 
to be $25.8 \%$ [19]. Similarly, a study in a tertiary care hospital in Pune, India, reported that $25.6 \%$ of the 78 nursing and medical students were susceptible to varicella infection [30]. A retrospective study conducted in a hospital in Vellore, India, revealed an annual varicella incidence rate of $0.72 \%$, increasing to a rate of $3.22 \%$ among student nurses; serological samples taken prior to admission revealed only $29.7 \%$ of student nurses produced antibodies against the varicella zoster virus [31]. A similar study conducted in the same institute 17 years later reported an annual incidence rate of $1.54 \%$ among student nurses [32].

Susceptibility to varicella can contribute to outbreaks of varicella infection. A varicella outbreak was reported in the intensive care unit of a tertiary care hospital in Punjab, India, where a nursing student was diagnosed with varicella after contact with a patient admitted because of a road traffic accident, who developed herpes zoster lesions. Subsequently, eight more HCPs caring for the patient across different shifts were diagnosed with varicella [33]. Another study conducted in a hospital in New Delhi, India, reported a nurse diagnosed with varicella after contact with an immunocompromised patient. In total, eight HCPs who came into contact with the same patient were also diagnosed with varicella [34]. Incidences of secondary and tertiary varicella outbreaks have also been reported among HCPs at a tertiary care hospital in Jaipur, India. The index case was an immunocompromised patient admitted with fever and pain in their abdomen who also showed signs of varicella infection. Of the six HCPs exposed to the patient, one had a history of varicella infection and the remaining five were vaccinated within $8 \mathrm{~h}$ of exposure. After approximately 2 weeks, six HCPs were diagnosed with varicella, three of whom were vaccinated. After approximately 10-21 days there were eight additional HCP cases. These HCPs had no prior direct contact with the patient but lived or worked with the HCPs who experienced the initial infections [35].

Outbreaks may also occur in the healthcare setting during medical procedures. Such an incident resulted from an autopsy of an immunocompromised patient, performed by 22
HCPs, including 19 medical students, one pathologist and two assistants. After approximately 2 weeks, one student was diagnosed with varicella, followed by three additional HCPs present during the autopsy. All infected HCPs had experienced splashes of blood on exposed areas and unbreeched skin. Two HCPs had a history of varicella infection, whereas the other two reported no prior varicella infection [36].

\section{Influenza}

In 2020, the National Centre of Disease Control in India reported 2752 cases of seasonal influenza and 44 deaths [37]. Infection from the influenza virus has always been a major concern for healthcare services, highlighted by several previous influenza pandemics. The influenza pandemic of 2009 , caused by a new influenza A virus subtype H1N1 (also referred to as 'swine $\mathrm{flu}^{\prime}$ ), spread rapidly within a short time, causing $>200,000$ deaths worldwide [38]. In a metaanalysis, the odds of infection with the H1N1 virus among HCPs were 2.08 with a pooled prevalence of $6.3 \%$ [39]. Reports from Pune, India (one of the worst affected cities during the 2009 pandemic) revealed that $21.3 \%$ of HCPs testing positive for $\mathrm{H} 1 \mathrm{~N} 1$ reported prior contact with diagnosed cases of H1N1 infection [40]. Moreover, in a seroepidemiology survey study conducted in Pune, $12.0 \%$ and $15.1 \%$ of hospital staff and general practitioners, respectively, tested seropositive for antibodies against H1N1 during the 2009 pandemic. This was considerably higher than the general population and was attributed to contact with patients presenting with influenza-like illness [41]. Increased risk of H1N1 transmission among HCPs working in the intensive care unit compared with those working in the community was also observed in a study conducted at the Christian Medical College, Vellore, India [42].

In terms of vaccination against influenza, vaccine coverage among HCPs in the US was $81.1 \%$ in $2018-2019$ [43]. An analysis by Haviari et al. showed that Croatia's influenza vaccine coverage was 19\% (2013) and in Greece it was $21 \%$ (2008); India was reported to have the 


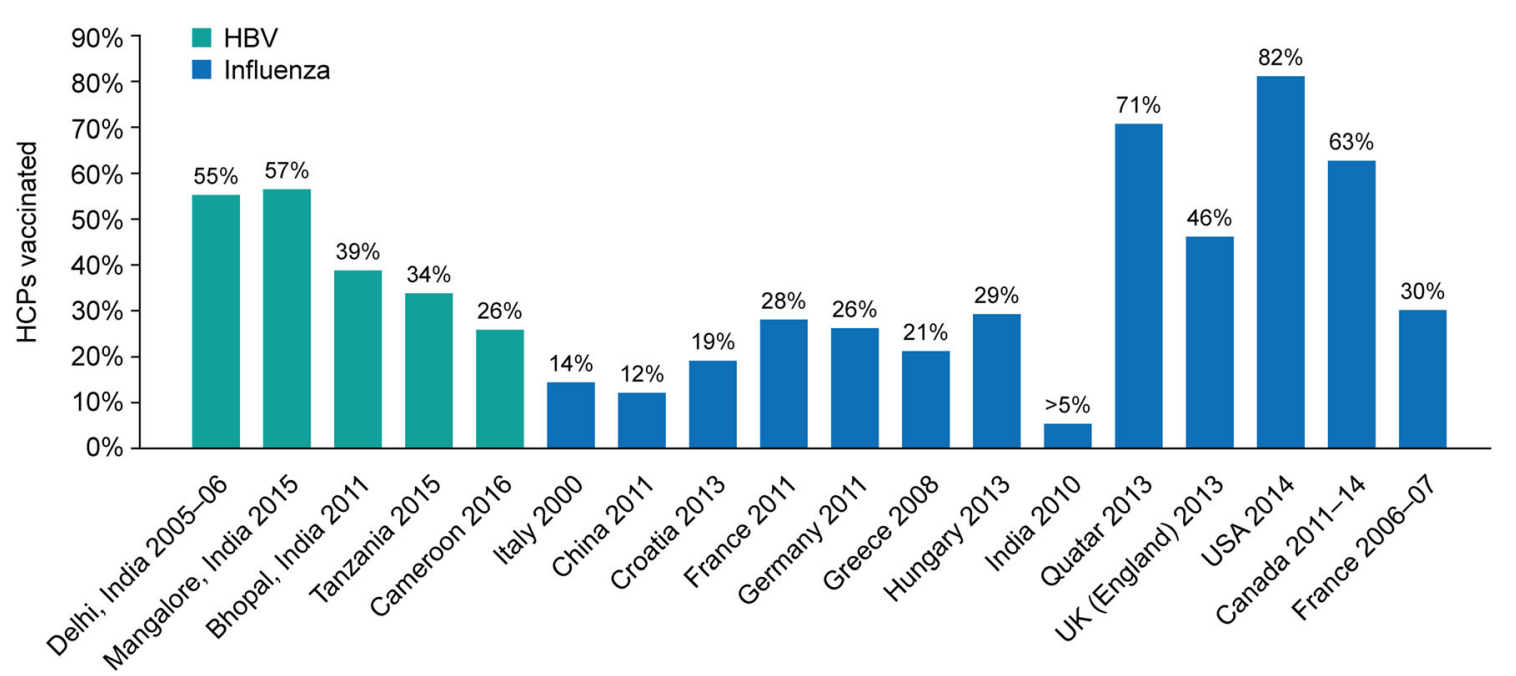

Fig. 3 Global hepatitis $B$ and influenza vaccination coverage among HCPs. Sources: Delhi: Sukriti, et al. J Gastroenterol Hepatol 2008;23:1710-5. Mangalore: Kumar HN, et al. Ann Glob Health 2015;81:664-8. Bhopal: Singh A. J Dent Educ 2011;75:421-7. Tanzania: Aaron D. BMC Infect Dis 2017;17:786. Cameroon: NDongo CB. J Viral Hepat 2018;25:1582-7. Italy:

lowest vaccination coverage of $<5 \%$ (2010) (Fig. 3) [28]. In addition, a study in Srinagar, India, observed that only $4.4 \%$ of HCPs had received vaccination against influenza at a frequency of 1-3 times in the last 5 years [16].

\section{Hepatitis A}

Hepatitis A virus (HAV) is transmitted primarily through the faecal-oral route and usually causes an acute, self-limiting liver infection and, in adults, can result in jaundice. Among HCPs, it has been shown that seropositivity for anti-HAV antibodies through previous exposure can vary because of factors including age, education, occupation, income and socio-economic class [44]. However, in India, a decline in infection rate in children due to improved living conditions has led to an increase in susceptible adults, who are more likely to have severe morbidity and mortality if not exposed in childhood [45-47]. This is highlighted by HAV outbreaks that have disproportionately affected adolescents and adults compared with children [48]. In Kerala, an outbreak in 1998 led to 399 cases of hepatitis A, $65 \%$ of which were in adults aged
Genovese C, et al. J Prev Med Hyg 2019;60:E12-E17. China, Croatia, France, Germany, Greece, Hungary, India, Qatar, UK (England), USA: Havairi S, et al. Hum Vaccin Immunother 2015;11:2522-37. Canada: Hussain H, et al. Influenza Other Respir Viruses 2018;12:319-25. France 2006-2007: Loulergue P, et al. Vaccine 2009;27:4240-3. $\mathrm{HBV}$, hepatitis B virus; HCP, healthcare provider

15-33 years [49]. In 2004, an outbreak occurred at a medical college hospital, also in Kerala; of 1180 cases, 540 were from the college, including 170 HCPs, and two deaths were reported among doctors [50]. Due to the historically high seroprevalence of HAV antibodies from a young age in India, there is no universal vaccination against HAV recommended for children, and HCPs are not universally included in the list of at-risk adults for whom a HAV vaccination is recommended [51, 52]. With an increasing population of adults who are seronegative for anti-HAV antibodies, vaccination is becoming increasingly important. Vaccination in children could provide protection into adulthood [53]; however, it is also important to consider broadening HAV vaccination coverage in adult populations, particularly for at-risk groups such as HCPs.

\section{Hepatitis B}

Hepatitis B virus (HBV) is transmitted through blood and bodily fluids. It infects the liver, causing acute or chronic hepatitis B. HBV infection among HCPs is an occupational 
Table 1 Needle stick injuries among Indian HCPs

\begin{tabular}{lllllll}
\hline \multicolumn{7}{l}{ HCPs experiencing needle stick injuries, \% } \\
\cline { 2 - 7 } & Consultants & Residents & Interns & Staff nurses & Lab technicians & Support staff \\
\hline Rishi E et al. 2017 & 21 & NR & 24 & 23 & 10 & 6 \\
Swetharani et al. 2016 & NR & 67.5 & NR & 34.1 & 10 & NR \\
Rajkumari N et al. 2014 & NR & NR & NR & 14.60 & 0.30 & 8.60 \\
Sharma A et al. 2012 & NR & 27.08 & 47 & 10.10 & NR & 1.10 \\
Sharma R et al. 2010 & NR & NR & 16.20 & 21.40 & 25.60 & NR \\
Mehta A et al. 2010 & 16 & NR & NR & 44 & 9 & 23 \\
Mehta A et al. 2005 & 11 & NR & NR & 45 & 11 & 33 \\
\hline
\end{tabular}

HCP, healthcare provider; NR, not reported

${ }^{a}$ Rishi E, et al. Indian J Ophthalmol 2017;65:999-1003

${ }^{\text {b }}$ Swetharani K, et al. Indian J Occup Environ Med 2016;20:138-43

${ }^{c}$ Rajkumari N, et al. Injury 2014;45:1470-78

dSharma A, et al. Indian J Public Health 2012;56:101-03

${ }^{\mathrm{e}}$ Sharma R, et al. Indian J Community Med 2010;35:74-7

${ }^{\mathrm{f}}$ Mehta A, et al. Indian J Med Microbiol 2010;28:17-20

${ }^{\mathrm{g}}$ Mehta A, et al. J Hosp Infect 2005;60:368-73

hazard because of frequent exposure to infectious bodily fluids. It has been estimated that globally around 3 million HCPs experience such exposure each year [54]. One of the most frequent ways HCPs are exposed to HBV is through needle stick injuries (NSIs). Several studies have been conducted assessing NSIs among HCPs in India (Table 1). Several HBV outbreaks in healthcare settings around the world have been reported, where the strain of $\mathrm{HBV}$ determines the severity of the resultant disease [55-58]. These studies highlight the need for additional efforts, beyond strict hygiene standards and adherence to standard precautions, to reduce the risk of HBV transmission in healthcare settings. Vaccination against HBV infection among HCPs is relatively low ranging between $25.8 \%$ and $55.4 \%$ in centres across India; vaccination coverage in some other areas of the world is also inadequate (Figs. 2, 3). In studies conducted in New Delhi and Bhopal, $44.6 \%$ of HCPs in New Delhi and $61.2 \%$ of HCPs in Bhopal were not vaccinated against HBV infection (including HCPs who did not know their vaccination status) $[54,59]$. Similarly, a study investigating the status of $\mathrm{HBV}$ vaccination among dental students found that only $45 \%$ of students were vaccinated against HBV [60].

\section{Tuberculosis}

Tuberculosis (TB) is one of the top ten causes of death worldwide [61]. TB in HCPs is of particular concern, with the average prevalence of latent TB infection in HCPs estimated to be $54 \%$ in low- and middle-income countries [62]. A meta-analysis of TB prevalence in HCPs revealed that TB infections are much more frequent among HCPs compared with the general population [63]. A study in India revealed that 50\% of HCPs may have latent TB infection measured either by a tuberculin skin test (TST) or interferon gamma release assay and a study in South India showed that $50.2 \%$ of nursing trainees tested were TST positive $[64,65]$. Incidence of pulmonary and extra-pulmonary $\mathrm{TB}$ among HCPs in India from 1992 to 2001 was estimated to be $0.37-1.57$ and $0.34-1.57$ per 1000 staff, respectively [66]. Moreover, HCPs are at constant risk of exposure to infection during 
management of patients with TB [67]. In the general population, TB vaccination coverage in infants has been estimated to be $92 \%$ in India [68]; however, there are no recommendations for TB vaccination of high-risk groups such as HCPs $[61,69]$.

\section{Meningococcal Disease}

Infection with meningococcal bacteria leads to meningitis and septicaemia with a fatality rate of up to $50 \%$ in untreated cases. In the hospital setting, a number of epidemics have been reported; however, there is limited information on the incidence of meningococcal disease in HCPs. Meningococcal vaccines are not routinely recommended in India, outside of epidemic situations [70].

\section{Diphtheria, Pertussis and Tetanus}

Diphtheria, pertussis and tetanus are transmitted through respiratory droplets (diphtheria and pertussis) or the direct transfer of spores through soil or faeces (tetanus). Pertussis can be particularly severe and deadly in young children; it easily transmits from adults to children, so infected HCPs may risk spreading this in hospitals. A vaccine targeting diphtheria, pertussis and tetanus has been used routinely in India since 1978, which significantly reduced incidence of disease in children. However, due to the duration of protection and need for boosters, it has led to concern over a potential shift of disease incidence into older age groups. In an investigation of male adults in Pune, India, who missed their initial vaccination, $88 \%, 100 \%$ and $79 \%$ of individuals were protected against diphtheria, tetanus and pertussis, respectively. However, long-term protection was only observed in 9\% for diphtheria and $74 \%$ for tetanus. After receiving the recommended diphtheria-tetanus vaccine, all participants were protected, with long-term protection achieved in $87 \%$ for diphtheria and $97 \%$ for tetanus [71]. This highlights the need for adult vaccination including HCPs, particularly in those who did not receive a vaccine in childhood.

\section{COVID-19}

Regarding COVID-19, India has been one of the worst affected countries [72]. Conservative estimates indicate 25,000 HCPs in India have been infected with SARS-CoV-2. One retrospective study from a tertiary care centre, medical college and hospital in North India reported that $16.3 \%$ of 3100 HCPs were positive for SARSCoV-2, with $45 \%$ being asymptomatic carriers [73]. HCPs were among the first to be offered the COVID-19 vaccination, and this rollout in the HCP population has been critical in slowing the pandemic not only in India but worldwide [74]. With HCPs continuing to be on the frontline, it will be vital to ensure they have adequate access to vaccinations to protect themselves and the patients they care for.

\section{BARRIERS TO VACCINATIONS FOR HCPS IN INDIA}

There is an unmet need to ensure HCPs in India are vaccinated against VPDs as HCP vaccination coverage is low. HCPs may face a variety of challenges and barriers in their professional life preventing vaccination against VPDs, such as inadequate resources, working environment and workload. Furthermore, the knowledge, attitude and perceptions of HCPs may vary between countries, regions and individual practices, with some HCPs more aware than others of the current vaccination guidelines and recommendations and the overall benefits of an effective vaccination programme. This, along with a poor understanding of the occupational hazards within the healthcare service, may impact vaccination uptake and HCP coverage.

Studies on vaccine hesitancy among HCPs in various countries worldwide reveal vaccine acceptance rates can range between $27.7 \%$ and $78.1 \%$. In the study by Bali NK et al. in Srinagar, India, influenza vaccine coverage among HCPs was only $4.4 \%$, despite $95 \%$ being aware of the adverse effects of influenza and $80.5 \%$ aware of the availability of the influenza vaccine [16]. Reasons for the low uptake included lack of awareness regarding vaccine availability, scepticism about efficacy, an unforgiving work schedule, concern about adverse events and a 
Table 2 Global barriers to vaccinations among HCPs

\begin{tabular}{|c|c|c|c|}
\hline HCPs (India) ${ }^{\mathbf{a}}$ & CHWs (India) ${ }^{b}$ & HCPs $(E U)^{c}$ & HCPs (China) ${ }^{d}$ \\
\hline Too busy to get vaccinated & $\begin{array}{l}\text { Required materials } \\
\text { unavailable }\end{array}$ & Already immune & $\begin{array}{l}\text { Obtained immunity } \\
\text { from work }\end{array}$ \\
\hline $\begin{array}{l}\text { Not aware of vaccines/lack of } \\
\text { knowledge }\end{array}$ & $\begin{array}{l}\text { Lack of updated and } \\
\text { practical information }\end{array}$ & $\begin{array}{l}\text { Inconvenient vaccination } \\
\text { timing and sites }\end{array}$ & $\begin{array}{l}\text { Hospitals not } \\
\text { providing vaccines }\end{array}$ \\
\hline $\begin{array}{l}\text { Vaccines are not available/freely } \\
\text { available }\end{array}$ & Use of medical terminology & $\begin{array}{l}\text { Fear of side effects, adjuvants } \\
\text { or ingredients }\end{array}$ & Too busy \\
\hline Doubts of vaccine efficacy and safety & $\begin{array}{l}\text { Lack of resources to gather } \\
\text { information }\end{array}$ & $\begin{array}{l}\text { Concerns over newer } \\
\text { vaccines }\end{array}$ & $\begin{array}{l}\text { Officially not } \\
\text { recommended }\end{array}$ \\
\hline Fear of side effects & Lack of time & $\begin{array}{l}\text { Low vaccine efficacy and } \\
\text { effectiveness }\end{array}$ & \\
\hline Needle phobia & & $\begin{array}{l}\text { Perceived low risk of } \\
\text { contracting diseases }\end{array}$ & \\
\hline \multicolumn{4}{|l|}{ Cost of vaccine } \\
\hline \multicolumn{4}{|l|}{$\begin{array}{l}\text { Low perception of susceptilibiliy/ } \\
\text { risk/contracting disease }\end{array}$} \\
\hline \multicolumn{4}{|l|}{ Disease not severe (e.g. influenza) } \\
\hline \multicolumn{4}{|l|}{ Egg allergy } \\
\hline \multicolumn{4}{|l|}{$\begin{array}{l}\text { Lack of understanding of disease/ } \\
\text { infection }\end{array}$} \\
\hline \multicolumn{4}{|c|}{$\begin{array}{l}\text { CHWs, community health workers; EU, European Union; HCP, healthcare provider } \\
\text { a'Sources: Bali NK, et al. Influenza Other Respir Viruses 2013;7:540-45; Pandey S, et al. Indian J Med Res } \\
\text { 2013;137:388-90; Dev K, et al. J Assoc Physicians India 2018;66:27-30; Pathak R, et al. Int J Med Public Health } \\
\text { 2013;3:55-9; Fazili AB, et al. Int J Med Res Health Sci 2016;5:115-20; Swarnapriya K, et al. Asian Pac J Cancer Prev } \\
\text { 2015;16:8473-7 } \\
\text { bSources: Raj S, et al. Health Info Libr J 2015;32:143-9 } \\
\text { cSource: ECDC 2015. Available from: https://www.ecdc.europa.eu/sites/default/files/media/en/publications/Publications/ } \\
\text { vaccine-hesitancy-among-healthcare-workers.pdf. Accessed September 2021 } \\
{ }^{\mathrm{d} S} \text { Source: Yuan Q, et al. PLoS One 2019;14:e0216598 }\end{array}$} \\
\hline
\end{tabular}

perception of not being at risk [16]. Regarding HBV, Dev K et al. [75] reported that only 35.3\% of HCPs knew about the risk of HBV transmission through NSIs and only $40 \%$ were aware of the protective measures to prevent NSIs. In addition, a study in Southern India revealed that, despite training, more than a third of HCPs failed to recognise the occupational hazards of NSIs [76]. A study from Delhi, India, also revealed significant differences $(p<0.001)$ in the level of knowledge among HCPs regarding the mode of influenza transmission, the use of protective equipment, the existing influenza treatment and vaccine availability [77].

Other studies highlight that such challenges and barriers exist in many countries [16, 78-80]. 
Table 3 Strategies to improve vaccination uptake among HCPs

\begin{tabular}{|c|c|c|}
\hline $\begin{array}{l}\text { For influenza and MMR } \\
\text { vaccinations }(\mathrm{UK})^{\mathrm{a}}\end{array}$ & $\begin{array}{l}\text { For influenza } \\
\text { vaccination (USA) }\end{array}$ & $\begin{array}{l}\text { For influenza } \\
\text { vaccination (India) }\end{array}$ \\
\hline $\begin{array}{l}\text { Provide vaccinations at } \\
\text { convenient times }\end{array}$ & Mobile carts & Regular monitoring \\
\hline Send more reminders & Free vaccines & Incentives for vaccination \\
\hline $\begin{array}{l}\text { Provide more information } \\
\text { on the advantages and } \\
\text { disadvantages of vaccines }\end{array}$ & $\begin{array}{l}\text { Adequate staff resources for } \\
\text { vaccine campaign }\end{array}$ & $\begin{array}{l}\text { Intensified advertising } \\
\text { campaign }\end{array}$ \\
\hline Advertise vaccination better & $\begin{array}{l}\text { Education on the benefits and } \\
\text { risks of immunisation }\end{array}$ & $\begin{array}{l}\text { Offer choice of influenza } \\
\text { vaccines }\end{array}$ \\
\hline $\begin{array}{l}\text { Free parking for staff at } \\
\text { vaccination sites }\end{array}$ & Incentives for vaccination & $\begin{array}{l}\text { Continuous education } \\
\text { of HCPs }\end{array}$ \\
\hline \multirow[t]{3}{*}{ Introduce peer vaccination } & $\begin{array}{l}\text { Availability at evenings } \\
\text { and weekends }\end{array}$ & $\begin{array}{l}\text { Mandatory vaccination policy } \\
\text { except when contraindicated }\end{array}$ \\
\hline & Availability at convenient places & $\begin{array}{l}\text { Convenient access to } \\
\text { vaccination at work }\end{array}$ \\
\hline & $\begin{array}{l}\text { Employment conditional } \\
\text { upon receipt of vaccine }\end{array}$ & \\
\hline
\end{tabular}

HCP, healthcare provider; MMR, measles, mumps and rubella; UK, United Kingdom; USA, United States of America ${ }^{a}$ Little KE, et al. Public Health 2015;129:755-62

${ }^{b}$ Weber DJ, et al. Isr J Health Policy Res 2016;5:61

${ }^{c}$ Bali NK, et al. Influenza Other Respir Viruses 2013;7:540-5

Most of these studies (Table 2) reveal poor awareness regarding vaccines among HCPs, poor availability of educational materials, a lack of updated information and a lack of information resources. These studies highlighted that HCPs were often too busy to get vaccinated and/ or did not perceive themselves as an 'at-risk' population. The reasons HCPs provided for not receiving a vaccine included inconvenient timing and location, cost, hospitals not providing free vaccines, needle phobia, concerns about vaccine safety and efficacy (especially for newer vaccines) and the lack of official recommendation to receive the vaccine.

Strategies must be implemented to overcome these challenges and barriers to improve HCP vaccination coverage. These may include providing adequate and up-to-date information on currently available vaccines through vaccination campaigns, frequent reminders for HCPs to get vaccinated, providing vaccinations at convenient times and places including the use of mobile carts, education around the risk of VPDs for HCPs and other measures as described in Table 3. The successful rollout of the COVID-19 vaccination programmes amongst HCPs, which has been critical in slowing the pandemic in India, will most likely positively influence the attitudes that HCPs have towards vaccinations. This provides an opportunity to educate and increase the awareness of vaccinations for HCPs.

\section{VACCINE RECOMMENDATIONS FOR HCPS}

Significant knowledge gaps and misperceptions exist among HCPs regarding vaccinations, the occupational hazards they may encounter and 
Table 4 Global, US and Indian recommendations for vaccinations in HCPs

\begin{tabular}{|c|c|c|c|c|c|}
\hline$\overline{\text { Vaccine }^{a}}$ & WHO $2019^{b}$ (Global) & $\begin{array}{l}\mathrm{CDC} / \mathrm{ACIP}^{\mathrm{c}} \\
\text { (US) }\end{array}$ & $\begin{array}{l}\text { The Indian } \\
\text { Association of } \\
\text { Occupational } \\
\text { Health } \\
(\text { IOAH })^{d}\end{array}$ & $\begin{array}{l}\text { Association of } \\
\text { Physicians in } \\
\text { India }(A P I)^{e}\end{array}$ & $\begin{array}{l}\text { Indian } \\
\text { Medical } \\
\text { Association } \\
(\text { IMA })^{\text {f }}\end{array}$ \\
\hline Hepatitis A & None & None & $\begin{array}{l}2 \text { doses (single } \\
\text { antigen } \\
\text { vaccine) }-0 \\
\text { and } \\
6-12 \text { months } \\
3 \text { doses (if } \\
\text { combined } \\
\text { hepatitis A } \\
\text { and B)-0, } 1 \\
\text { and } 6 \text { months }\end{array}$ & Not recommended & $\begin{array}{l}2 \text { doses } \\
\text { (inactivated } \\
\text { vaccine)- } \\
0-6 \text { months } \\
1 \text { dose (live } \\
\text { vaccine) }\end{array}$ \\
\hline Hepatitis $\mathrm{B}^{\mathrm{g}}$ & $\begin{array}{l}\text { Unvaccinated who may } \\
\text { be exposed to blood and } \\
\text { blood products at work }\end{array}$ & $\begin{array}{l}\text { Unvaccinated/ } \\
\text { incomplete series } \\
\text { or no } \\
\text { vaccination } \\
\text { history, no up- } \\
\text { to-date } \\
\text { immunity status } \\
2 \text { doses-0 and } \\
1 \text { month } \\
3 \text { doses-0, } 1 \text { and } \\
5 \text { months after } \\
\text { dose } 2 \\
\text { Anti-HBs serology } \\
1-2 \text { months after } \\
\text { final dose }\end{array}$ & $\begin{array}{l}3 \text { doses }-0,1 \\
\text { and } 6 \text { months }\end{array}$ & $\begin{array}{l}3 \text { doses-0, } 1 \text { and } \\
6 \text { months }\end{array}$ & $\begin{array}{l}3 \text { doses }-0,1 \\
\text { and } 6 \text { months }\end{array}$ \\
\hline MMR & $\begin{array}{l}\text { Proof/documentation of } \\
\text { immunity or } \\
\text { immunisation should } \\
\text { be required as a } \\
\text { condition of enrolment } \\
\text { into training and } \\
\text { employment } \\
\text { HCPs are not at risk of } \\
\text { mumps }\end{array}$ & $\begin{array}{l}\text { Born in } 1957 \text { or } \\
\text { later with no } \\
\text { MMR } \\
\text { vaccination or } \\
\text { up-to-date } \\
\text { immune status } \\
2 \text { doses of } \mathrm{MMR}^{\mathrm{h}} \\
\text { (gap of } 28 \text { days) }\end{array}$ & $\begin{array}{l}2 \text { MMR doses - } \\
\text { 4-8-week } \\
\text { interval } \\
1 \text { dose if } \\
\text { previously } \\
\text { immunised }\end{array}$ & 2 MMR doses & $\begin{array}{l}2 \text { MMR } \\
\text { doses-4-8- } \\
\text { week interval }\end{array}$ \\
\hline Meningococcal & $\begin{array}{l}\text { One booster dose } \\
3-5 \text { years after the } \\
\text { primary dose may be } \\
\text { given to persons } \\
\text { considered to be at } \\
\text { continued risk of } \\
\text { exposure }\end{array}$ & $\begin{array}{l}1 \text { dose for those } \\
\text { who are } \\
\text { routinely } \\
\text { exposed to } \\
\text { isolates of } \\
\text { Neisseria } \\
\text { meningitidis }\end{array}$ & $\begin{array}{l}1 \text { or } 2 \text { doses } \\
\text { Booster every } \\
5 \text { years if risk } \\
\text { remains }\end{array}$ & $\begin{array}{l}1 \text { dose-during an } \\
\text { outbreak }\end{array}$ & $\begin{array}{l}1 \text { dose } \\
\text { Repeat after } \\
3-5 \text { years if } \\
\text { high risk }\end{array}$ \\
\hline Influenza & $\begin{array}{l}\text { Annual immunisation } \\
\text { with a single dose is } \\
\text { recommended }\end{array}$ & 1 dose-every year & $\begin{array}{l}1 \text { dose-every } \\
\text { year }\end{array}$ & Not recommended & $\begin{array}{l}1 \text { dose-every } \\
\text { year }\end{array}$ \\
\hline
\end{tabular}


Table 4 continued

\begin{tabular}{|c|c|c|c|c|c|}
\hline Vaccine $^{a}$ & WHO 2019 ${ }^{\mathrm{b}}$ (Global) & $\begin{array}{l}{\mathrm{CDC} / \mathrm{ACIP}^{\mathrm{c}}} \\
\text { (US) }\end{array}$ & $\begin{array}{l}\text { The Indian } \\
\text { Association of } \\
\text { Occupational } \\
\text { Health } \\
(\text { IOAH })^{d}\end{array}$ & $\begin{array}{l}\text { Association of } \\
\text { Physicians in } \\
\text { India (API) }\end{array}$ & $\begin{array}{l}\text { Indian } \\
\text { Medical } \\
\text { Association } \\
\text { (IMA) }^{\mathrm{f}}\end{array}$ \\
\hline Varicella & $\begin{array}{l}\text { Unvaccinated and with } \\
\text { no history of varicella } \\
\text { infection } \\
2 \text { doses of varicella vaccine }\end{array}$ & $\begin{array}{l}\text { No history of } \\
\text { varicella } \\
\text { infection or } \\
\text { vaccination or } \\
\text { unknown } \\
\text { immune status } \\
2 \text { doses, } 4 \text { weeks } \\
\text { apart }\end{array}$ & $\begin{array}{l}2 \text { doses-4-8- } \\
\text { week interval } \\
1 \text { dose-if } \\
\text { previously } \\
\text { vaccinated }\end{array}$ & $\begin{array}{l}2 \text { doses_-4-8-week } \\
\text { interval }\end{array}$ & $\begin{array}{l}2 \text { doses-4-8- } \\
\text { week interval }\end{array}$ \\
\hline $\begin{array}{l}\text { Tetanus } \\
\text { Diphtheria }\end{array}$ & $\begin{array}{l}\text { None } \\
\text { Revaccination of HCPs } \\
\text { with diphtheria } \\
\text { boosters every } 10 \text { years, } \\
\text { especially those who } \\
\text { may have occupational } \\
\text { exposure }\end{array}$ & $\begin{array}{l}\text { One-time Tdap } \\
\text { dose } \\
\text { immediately if } \\
\text { not received } \\
\text { earlier (despite } \\
\text { previous Td) } \\
\text { Td/Tdap boosters }\end{array}$ & $\begin{array}{l}1 \text { dose of } \\
\text { Tdap-then } \\
\text { Td booster } \\
\text { every } 10 \text { years }\end{array}$ & $\begin{array}{l}1 \text { dose of Tdap-if } \\
\text { not received } \\
\text { Tdap vaccine } \\
\text { before } \\
\text { and } \geq 2 \text { years } \\
\text { since last } \mathrm{Td} \\
\text { vaccine }\end{array}$ & $\begin{array}{l}1 \text { dose of } \\
\text { Tdap-every } \\
10 \text { years }\end{array}$ \\
\hline Pertussis & $\begin{array}{l}\text { HCPs should be a } \\
\text { prioritised population }\end{array}$ & $\begin{array}{l}\text { every } 10 \text { years } \\
\text { Pregnant HCPs } \\
\text { need Tdap in } \\
\text { each pregnancy }\end{array}$ & & $\begin{array}{l}\text { Td booster every } \\
10 \text { years }\end{array}$ & \\
\hline Polio & $\begin{array}{l}\text { All HCPs should have } \\
\text { completed primary } \\
\text { doses }\end{array}$ & None & $\begin{array}{l}1 \text { or } 2 \text { doses (if } \\
\text { unvaccinated } \\
)-0 \\
4-8 \text { weeks }\end{array}$ & None & $\begin{array}{l}1 \text { or } 2 \text { doses (if } \\
\text { unvaccinated } \\
)-0 \text {, } \\
4-8 \text { weeks }\end{array}$ \\
\hline Pneumococcal & None & $\begin{array}{l}\text { Not stated } \\
\text { specifically for } \\
\text { HCPs }\end{array}$ & $\begin{array}{l}\text { PCV13 } 1 \text { dose } \\
\text { PPSV23 } 1 \text { dose }\end{array}$ & Not recommended & $\begin{array}{l}\text { Not stated } \\
\text { specifically } \\
\text { for HCPs }\end{array}$ \\
\hline Typhoid & None & $\begin{array}{l}\text { Microbiologists } \\
\text { and others who } \\
\text { work frequently } \\
\text { with Salmonella } \\
\text { Typhi }\end{array}$ & 1 dose & $\begin{array}{l}3 \text { doses - for entire } \\
\text { community } \\
\text { during outbreaks } \\
\text { Booster every } \\
3 \text { years }\end{array}$ & $\begin{array}{l}1 \text { single dose } \\
\text { If un- } \\
\text { conjugated } \\
\text { vaccine give } \\
\text { every } 3 \text { years }\end{array}$ \\
\hline Rabies & $\begin{array}{l}\text { HCPs may receive pre- } \\
\text { exposure prophylaxis if } \\
\text { they are regularly caring } \\
\text { for patients with rabies }\end{array}$ & None & $\begin{array}{l}\text { 3-4 doses } \\
\text { PEP-0, } 7 \\
21,28 \text { days }\end{array}$ & $\begin{array}{l}3 \text { doses } P E P-0,7 \text {, } \\
28 \text { days }\end{array}$ & $\begin{array}{l}3 \text { doses PEP- } \\
0,7,28 \text { days } \\
\text { (especially in } \\
\text { veterinarians) }\end{array}$ \\
\hline
\end{tabular}


Table 4 continued

\begin{tabular}{llllll}
\hline Vaccine $^{\mathbf{a}}$ & WHO 2019 $^{\mathbf{b}}$ (Global) & $\begin{array}{l}\text { CDC/ACIP } \\
(\mathbf{U S})\end{array}$ & $\begin{array}{l}\text { The Indian } \\
\text { Association of } \\
\text { Occupational } \\
\text { Health } \\
(\mathbf{I O A H})^{\mathbf{d}}\end{array}$ & $\begin{array}{l}\text { Association of } \\
\text { Physicians in } \\
\text { India (API) }\end{array}$ & $\begin{array}{l}\mathbf{~}^{\mathbf{I}} \\
\text { Median } \\
\text { Association } \\
(\text { IMA })^{\mathbf{f}}\end{array}$ \\
\hline COVID-19 $^{\mathrm{i}}$ & $\begin{array}{c}\text { HCPs should be a } \\
\text { prioritised population }\end{array}$ & $\begin{array}{l}\text { HCPs should be a } \\
\text { prioritised } \\
\text { population }\end{array}$ & None & None & None \\
\hline
\end{tabular}

ACIP, Advisory Committee on Immunization Practices; BCG, Bacillus Calmette-Guérin; CDC, Centres for Disease Control; HBs, hepatitis B surface antibody; HCP, healthcare provider; IGRA, interferon-gamma release assay; MMR, measles, mumps and rubella; PCV13, pneumococcal conjugate vaccine; PEP, pre-exposure prophylaxis; PPSV23, pneumococcal polysaccharide vaccine; TB, tuberculosis; $\mathrm{Td}$, tetanus and diphtheria; Tdap, tetanus, diphtheria and pertussis; TST, tuberculin skin test; US, United States; WHO, World Health Organization

${ }^{a}$ No specific recommendations for HCPs for cholera and yellow fever. Only the WHO provides recommendations for BCG (TB) vaccination: In unvaccinated TST- or IGRA-negative persons at risk of occupational exposure in low and high TB incidence areas

bSource: WHO. 2020. Available from: https://www.who.int/immunization/policy/Immunization_routine_table4.pdf. Accessed September 2021 and COVID-19 specific: https://www.who.int/docs/default-source/immunization/sage/covid/ sage-prioritization-roadmap-covid19-vaccines.pdf?Status=Temp\&sfvrsn=bf227443_2 Accessed September 2021

'Source: CDC (and ACIP). 2021. Available from: https://www.cdc.gov/vaccines/adults/rec-vac/hcw.html and https:// www.cdc.gov/mmwr/preview/mmwrhtml/rr6007a1.htm Accessed September 2021 and COVID-19 specific: https://www. cdc.gov/coronavirus/2019-ncov/vaccines/recommendations/hcp.html and https:/www.cdc.gov/coronavirus/2019-ncov/ vaccines/recommendations-process.html Accessed September 2021

dSource: IAOH. 2020. Available from: http://storage.unitedwebnetwork.com/files/162/ b8a89025513aba3a9c888c097e204122.pdf. Accessed September 2021

'Source: API Guidelines. 2009. Available from: https://www.japi.org/s274e444/executive-summary-the-association-ofphysicians-of-india-evidence-based-clinical-practice-guidelines-on-adult-immunization. Accessed September 2021

Source: IMA. 2018. Available from: http://www.ima-india.org/ima/pdfdata/IMA_LifeCourse_Immunization_Guide_ 2018_DEC21.pdf. Accessed September 2021

Post-vaccination testing may be required after 1-2 months of last dose

${ }^{\mathrm{h}}$ One dose of rubella recommended, eventually two doses will be needed as standalone rubella vaccine is not available

${ }^{\mathrm{i}}$ Vaccination based on local recommendations

the risk they pose if they go unvaccinated. In addition, there are no complete, standardised guidelines for vaccinations among HCPs and discrepancies have been observed in the Indian recommendations. Thus, uniform guidelines should be developed detailing the recommendations for vaccinations in all HCPs across every healthcare unit in India. Such initiatives will protect HCPs, their families and patients, interrupt the spread and transmission of diseases and help maintain healthcare services. Current vaccine recommendations for HCPs are provided in Table 4.

\section{DISCUSSION}

HCPs are the frontline workforce tackling infectious disease. Their occupation puts them at risk while caring for patients and this is magnified during disease outbreaks, epidemics and pandemics. They work in a hazardous environment, which is often unpredictable and may lead to physical, mental and social stress. Therefore, HCPs may be directly or indirectly at risk of exposure to infection and VPDs as they work close to their patients.

Our review highlights that HCPs susceptible to VPDs can contribute to nosocomial infection or disease outbreaks within the community and that there is a gap between vaccination coverage 
and disease awareness among HCPs in India, despite training $[16,20,22-24,75,76]$. Moreover, challenges and barriers regarding vaccination awareness and uptake exist among HCPs, highlighted in a study by Tandale BV et al. [41], that showed general practitioners have few infection-control measures and were at a higher risk of infection compared with hospital staff.

Therefore, protection and immunisation of HCPs against VPDs should be of utmost interest. Vaccine education amongst HCPs is one pivotal strategy that could support this initiative. For example, a study by Bali NK et al. showed that an educational journey regarding the influenza vaccination, including its tolerability and efficacy, will be beneficial for all HCPs [16]. Such initiatives will be considered as a complementary step towards national initiatives for VPD control and elimination. In our review, we observed that there are several guidelines that recommend HCP vaccination, although there are differences and discrepancies in their specific recommendations. Thus, a uniform policy in an Indian context should be developed, appropriately implemented and routinely followed up, so the spread of VPDs and disease outbreaks can be prevented or controlled.

\section{EXPERT OPINION}

Immunisation of HCPs is important to reduce the transmission and/or acquisition of some diseases. HCP vaccination status assessment is recommended before their duty rosters are prepared and assigned and before they encounter vulnerable patients. Moreover, screening and vaccination records should be maintained for all HCPs across the various healthcare departments to aid in any follow-up or further action. If the cost of screening and documentation of immunity are an additional burden on healthcare expenditure, it might be prudent to vaccinate each HCP at the time of admission (after considering the cost-benefit ratio), considering that vaccination is more cost-effective than screening (both serology and/or medical history). An additional strategy to increase HCP vaccination could include sharing updates on airborne infections, VPDs and disease outbreaks across the healthcare setting, through text messages, emails or print media. Applying these measures may help HCPs protect themselves, their family members, peers and patients without disrupting healthcare services.

\section{CONCLUSION}

In India and across the world, HCPs are the backbone of healthcare institutions, often working for long hours in a hazardous environment. They are vulnerable to VPDs and play a major role in nosocomial infections. Induction training programmes on disease awareness along with screening and vaccination should be implemented at respective institutes across India to resolve several misperceptions and beliefs regarding vaccinations. In addition, it will be important to immunise all HCPs, not just those who are in direct contact with patients. Hospital and clinic administrations must be proactive against VPDs and should develop guidelines and implement vaccination programmes as a standard policy. A dedicated infrastructure towards implementation of vaccination policies in HCPs and prevention of disease through vaccination alongside other preventive measures should be considered as a priority for limiting nosocomial infections.

\section{ACKNOWLEDGEMENTS}

Funding. GlaxoSmithKline Biologicals SA funded the research and was involved in all stages of its conduct, including analysis and interpretation of the data. GlaxoSmithKline Biologicals SA also funded all costs associated with the development and publication of this manuscript.

Medical writing, editorial and other assistance. The authors thank MediTech Media for editorial assistance and manuscript coordination on behalf of GSK Vaccines. Sam Thorburn provided medical writing support and Danielle 
Lindley coordinated manuscript development and editorial support.

Authorship. All named authors meet the International Committee of Medical Journal Editors (ICMJE) criteria for authorship for this article, take responsibility for the integrity of the work as a whole, and have given their approval for this version to be published.

Author Contributions. Mallavalli Surendranath, Ravi Wankhedkar, Jayesh Lele, Otavio Cintra, Shafi Kolhapure, Ashish Agrawal, and Pavitra Dewda, contributed equally to the conception, analysis and interpretation of data as well as the development of this review and approved the final version.

Disclosures. Mallavalli Surendranath, Ravi Wankhedkar and Jayesh Lele have nothing to disclose. Otavio Cintra, Shafi Kolhapure, Ashish Agrawal and Pavitra Dewda are employed by, and have stock ownership in, the GSK Group of Companies.

Compliance with Ethics Guidelines. This article is based on previously conducted studies and does not contain any new studies with human participants or animals performed by any of the authors.

Data Availability. Data sharing is not applicable to this article as no datasets were generated or analysed.

Open Access. This article is licensed under a Creative Commons Attribution-NonCommercial 4.0 International License, which permits any non-commercial use, sharing, adaptation, distribution and reproduction in any medium or format, as long as you give appropriate credit to the original author(s) and the source, provide a link to the Creative Commons licence, and indicate if changes were made. The images or other third party material in this article are included in the article's Creative Commons licence, unless indicated otherwise in a credit line to the material. If material is not included in the article's Creative Commons licence and your intended use is not permitted by statutory regulation or exceeds the permitted use, you will need to obtain permission directly from the copyright holder. To view a copy of this licence, visit http://creativecommons.org/licenses/by$\mathrm{nc} / 4.0 /$.

\section{REFERENCES}

1. CDC. Immunization of Health-Care Personnel: Recommendations of the Advisory Committee on Immunization Practices (ACIP). 2011. https://www. cdc.gov/mmwr/preview/mmwrhtml/rr6007a1. $\mathrm{htm} /$.

2. Joseph B, Joseph M. The health of the healthcare workers. Indian J Occup Environ Med. 2016;20(2): 71-2.

3. O'Reilly F, Dolan GP, Nguyen-Van-Tam J, Noone P. Practical prevention of nosocomial influenza transmission, "a hierarchical control" issue. Occup Med (Lond). 2015;65(9):696-700.

4. Uyeki TM. High-risk groups for influenza complications. JAMA. 2020;324(22):2334.

5. Hansen S, Stamm-Balderjahn S, Zuschneid I, Behnke M, Ruden H, Vonberg RP, et al. Closure of medical departments during nosocomial outbreaks: data from a systematic analysis of the literature. J Hosp Infect. 2007;65(4):348-53.

6. Adams JG, Walls RM. Supporting the health care workforce during the COVID-19 global epidemic. JAMA. 2020;323(15):1439-40.

7. Koh D. Occupational risks for COVID-19 infection. Occup Med (Lond). 2020;70(1):3-5.

8. Sydnor E, Perl TM. Healthcare providers as sources of vaccine-preventable diseases. Vaccine. 2014;32(38):4814-22.

9. IBEF. Healthcare Industry in India 2021. 2021. https://www.ibef.org/industry/healthcare-india. aspx. Accessed 7 May.

10. FICCI. Medical Tourism in India 2019. 2019. http:// ficci.in/ficci-in-news-page.asp?nid=17703.

11. Kumar R, Pal R. India achieves WHO recommended doctor population ratio: a call for paradigm shift in public health discourse! J Family Med Prim Care. 2018;7(5):841-4. 
12. Kumar R. Family medicine takes center stage in India: National Medical Commission Act 2019. J Family Med Prim Care. 2020;9(3):1281-2.

13. Karan A, Negandhi H, Nair R, Sharma A, Tiwari R, Zodpey S. Size, composition and distribution of human resource for health in India: new estimates using National Sample Survey and Registry data. BMJ Open. 2019;9(4):e025979.

14. Kasthuri A. Challenges to healthcare in India-the Five A's. Indian J Community Med. 2018;43(3): 141-3.

15. Gurnani V, Haldar P, Aggarwal MK, Das MK, Chauhan A, Murray J, et al. Improving vaccination coverage in India: lessons from Intensified Mission Indradhanush, a cross-sectoral systems strengthening strategy. BMJ (Clin Res Ed). 2018;363:k4782.

16. Bali NK, Ashraf M, Ahmad F, Khan UH, Widdowson MA, Lal RB, et al. Knowledge, attitude, and practices about the seasonal influenza vaccination among healthcare workers in Srinagar, India. Influenza Other Respir Viruses. 2013;7(4):540-5.

17. Dinh A, Fleuret V, Hanslik T. Liver involvement in adults with measles. Int J Infect Dis. 2013;17(12): e1243-4.

18. Chassort A, Coutherut J, Moreau-Klein A, Gras-Le Guen C, Trewick D, Raffi F, et al. Renal dysfunction in adults during measles. Med Mal Infect. 2015;45(5):165-8.

19. Arunkumar G, Vandana KE, Sathiakumar N. Prevalence of measles, mumps, rubella, and varicella susceptibility among health science students in a University in India. Am J Ind Med. 2013;56(1): 58-64.

20. Bajaj S, Bobdey P, Singh N. Measles outbreak in adults: a changing epidemiological pattern. Med J Dr DY Patil Univ. 2017;10(5):447-52.

21. Singh MP, Diddi K, Dogra S, Suri V, Varma S, Ratho RK. Institutional outbreak of rubella in a healthcare center in Chandigarh, North India. J Med Virol. 2010;82(2):341-4.

22. Singh MP, Chatterjee SS, Singh R, Goyal K, Ratho RK. Rubella seronegativity among health care workers in a tertiary care north Indian hospital: implications for immunization policy. Indian J Pathol Microbiol. 2013;56(2):148-50.

23. Shekhar S, Nag VL, Singh P, Kaushal R, Batra S, Chandra C. Rubella seroprevalence among indian female medical and nursing students at a tertiary care teaching institute and its correlation with socioeconomic status. Indian J Community Med. 2020;45(2):246-7.
24. Rajasundari TA, Chandrasekar K, Vijayalakshmi P, Muthukkaruppan V. Immune status of health care personnel \& post vaccination analysis of immunity against rubella in an eye hospital. Indian J Med Res. 2006;124(5):553-8.

25. Singla N, Jindal N, Aggarwal A. The seroepidemiology of Rubella in Amritsar (Punjab). Indian J Med Microbiol. 2004;22(1):61-3.

26. Vijayalakshmi P, Anuradha R, Prakash K, Narendran K, Ravindran M, Prajna L, et al. Rubella serosurveys at three Aravind Eye Hospitals in Tamil Nadu. India Bull World Health Organ. 2004;82(4):259-64.

27. Denny JT, Rocke ZM, McRae VA, Denny JE, Fratzola $\mathrm{CH}$, Ibrar S, et al. Varicella pneumonia: case report and review of a potentially lethal complication of a common disease. J Investig Med High Impact Case Rep. 2018;6:2324709618770230.

28. Haviari S, Bénet T, Saadatian-Elahi M, André P, Loulergue P, Vanhems P. Vaccination of healthcare workers: a review. Hum Vaccin Immunother. 2015;11(11):2522-37.

29. Shah S, Singhal T, Naik R, Thakkar P. High prevalence of varicella seronegativity in nurses at a tertiary care private hospital in Mumbai, India. Indian J Med Microbiol. 2018;36(2):294-5.

30. Singru SA, Tilak VW, Gandham N, Bhawalkar JS, Jadhav SL, Pandve HT. Study of susceptibility towards varicella by screening for the presence of IgG antibodies among nursing and medical students of a tertiary care teaching hospital in Pune, India. J Glob Infect Dis. 2011;3(1):37-41.

31. Venkitaraman AR, John TJ. The epidemiology of varicella in staff and students of a hospital in the tropics. Int J Epidemiol. 1984;13(4):502-5.

32. Richard VS, John TJ, Kenneth J, Ramaprabha P, Kuruvilla PJ, Chandy GM. Should health care workers in the tropics be immunized against varicella? J Hosp Infect. 2001;47(3):243-5.

33. Sarit S, Shruti S, Deepinder C, Chhina RS. Chicken pox outbreak in the Intensive Care Unit of a tertiary care hospital: Lessons learnt the hard way. Indian J Crit Care Med. 2015;19(12):723-5.

34. Singh H, Pandya KH, Bhatti VK, Lathwal S, Kumar M. Outbreak control of hospital acquired varicella infection amongst health care workers in a tertiary care hospital. Med J Armed Forces India. 2020. ISSN 0377-1237.https://doi.org/10.1016/j.mjafi.2019.12. 004 .

35. Sood S. Occupationally related outbreak of chickenpox in hospital staff: a learning experience. J Clin Diagn Res. 2013;7(10):2294-5. 
36. Paul N, Jacob ME. An outbreak of cadaver-acquired chickenpox in a health care setting. Clin Infect Dis. 2006;43(5):599-601.

37. NCDC. Seasonal Influenza A (H1N1): State/UT- wise number of cases \& deaths from 2016 to 2021 (As on 30.04.2021). 2021. https://ncdc.gov.in/showfile. php?lid=280. Accessed 10 May.

38. Dawood FS, Iuliano AD, Reed C, Meltzer MI, Shay DK, Cheng PY, et al. Estimated global mortality associated with the first 12 months of 2009 pandemic influenza A H1N1 virus circulation: a modelling study. Lancet Infect Dis. 2012;12(9):687-95.

39. Lietz J, Westermann C, Nienhaus A, Schablon A. The occupational risk of influenza A (H1N1) infection among healthcare personnel during the 2009 pandemic: a systematic review and meta-analysis of observational studies. PLoS ONE. 2016;11(8): e0162061.

40. Pandey S, Kushwaha AS, Mahen A. H1N1 vaccination profile of health care workers \& medical students. Indian J Med Res. 2013;137(2):388-90.

41. Tandale BV, Pawar SD, Gurav YK, Chadha MS, Koratkar SS, Shelke VN, et al. Seroepidemiology of pandemic influenza A (H1N1) 2009 virus infections in Pune, India. BMC Infect Dis. 2010;10:255.

42. Moorthy M, Chacko B, Ramakrishna K, Samuel P, Karthik G, Kalki RC, et al. Risk of pandemic (H1N1) 2009 virus infection among healthcare workers caring for critically ill patients with pandemic (H1N1) 2009 virus infection. J Hosp Infect. 2011;77(4):365-6.

43. CDC. Influenza vaccination coverage among health care personnel-United States, 2018-19 influenza season. 2019. https://www.cdc.gov/flu/fluvaxview/ hcp-coverage_1819estimates.htm. Accessed 26 Sep 2019.

44. Chauhan S, Agarwal J, Jain A, Sawlani KK, Gupta P, Goel A, et al. Status of adult immunity to hepatitis A virus in healthcare workers from a tertiary care hospital in north India. Indian $\mathrm{J}$ Med Res. 2019;150(5):508-11.

45. Kar P. Is there a change in seroepidemiology of hepatitis A infection in India? Indian J Med Res. 2006;123(6):727-9.

46. Mathur P, Arora NK. Epidemiological transition of hepatitis A in India: issues for vaccination in developing countries. Indian $\mathrm{J}$ Med Res. 2008;128(6):699-704.

47. Raju B, Andani A, Kolhapure S, Agrawal A. Need for hepatitis A prevention in patients with chronic liver disease in the changing epidemiological setting of India. Hum Vaccin Immunother. 2020;2020:1-10.

48. Agrawal A, Singh S, Kolhapure S, Hoet B, Arankalle $\mathrm{V}$, Mitra M. Increasing burden of hepatitis A in adolescents and adults and the need for long-term protection: a review from the Indian subcontinent. Infect Dis Ther. 2019;8(4):483-97.

49. Rakesh P, Sherin D, Sankar H, Shaji M, Subhagan S, Salila S. Investigating a community-wide outbreak of hepatitis a in India. J Glob Infect Dis. 2014;6(2): 59-64.

50. Arankalle VA, Sarada Devi KL, Lole KS, Shenoy KT, Verma V, Haneephabi M. Molecular characterization of hepatitis A virus from a large outbreak from Kerala, India. Indian J Med Res. 2006;123(6):760-9.

51. Batra Y, Bhatkal B, Ojha B, Kaur K, Saraya A, Panda $\mathrm{SK}$, et al. Vaccination against hepatitis A virus may not be required for schoolchildren in northern India: results of a seroepidemiological survey. Bull World Health Organ. 2002;80(9):728-31.

52. Koul PA, Swaminathan S, Rajgopal T, Ramsubramanian V, Joseph B, Shanbhag S, et al. Adult immunization in occupational settings: a consensus of Indian experts. Indian J Occup Environ Med. 2020;24(1):3-15.

53. Agrawal A, Kolhapure S, Andani A, Ota MOC, Badur $\mathrm{S}$, Karkada N, et al. Long-term persistence of antibody response with two doses of inactivated hepatitis A vaccine in children. Infect Dis Ther. 2020;9(4):785-96.

54. Sukriti A, Pati NT, Sethi A, Agrawal K, Agrawal K, Kumar GT, et al. Low levels of awareness, vaccine coverage, and the need for boosters among health care workers in tertiary care hospitals in India. J Gastroenterol Hepatol. 2008;23(11):1710-5.

55. Seiz PL, Slanina H, Ziebuhr J, Gerlich WH, Glebe D, Schüttler CG. Studies of nosocomial outbreaks of hepatitis B in nursing homes in Germany suggest a major role of hepatitis $B$ e antigen expression in disease severity and progression. Int J Med Microbiol. 2015;305(7):663-72.

56. Duffell EF, Milne LM, Seng C, Young Y, Xavier S, King $S$, et al. Five hepatitis $B$ outbreaks in care homes in the UK associated with deficiencies in infection control practice in blood glucose monitoring. Epidemiol Infect. 2011;139(3):327-35.

57. Burns K, Heslin J, Crowley B, Thornton L, Laoi BN, Kelly E, et al. Nosocomial outbreak of hepatitis B virus infection involving two hospitals in the Republic of Ireland. J Hosp Infect. 2011;78(4):279-83. 
58. Pourkarim MR, Verbeeck J, Rahman M, AminiBavil-Olyaee S, Forier AM, Lemey P, et al. Phylogenetic analysis of hepatitis $B$ virus full-length genomes reveals evidence for a large nosocomial outbreak in Belgium. J Clin Virol. 2009;46(1):61-8.

59. Singh A, Purohit BM, Bhambal A, Saxena S, Singh A, Gupta A. Knowledge, attitudes, and practice regarding infection control measures among dental students in Central India. J Dent Educ. 2011;75(3):421-7.

60. Khandelwal V, Khandelwal S, Gupta N, Nayak UA, Kulshreshtha N, Baliga S. Knowledge of hepatitis B virus infection and its control practices among dental students in an Indian city. Int J Adolesc Med Health. 2017;30:5.

61. WHO. Global tuberculosis report 2020 Geneva. 2020. https://apps.who.int/iris/bitstream/handle/ 10665/336069/9789240013131-eng.pdf.

62. Joshi R, Reingold AL, Menzies D, Pai M. Tuberculosis among health-care workers in low- and middle-income countries: a systematic review. PLoS Med. 2006;3(12):e494.

63. Uden L, Barber E, Ford N, Cooke GS. Risk of tuberculosis infection and disease for health care workers: an updated meta-analysis. Open Forum Infect Dis. 2017;4(3):ofx137.

64. Pai M, Gokhale K, Joshi R, Dogra S, Kalantri S, Mendiratta DK, et al. Mycobacterium tuberculosis infection in health care workers in rural India: comparison of a whole-blood interferon gamma assay with tuberculin skin testing. JAMA. $2005 ; 293(22): 2746-55$.

65. Christopher DJ, Daley P, Armstrong L, James P, Gupta R, Premkumar B, et al. Tuberculosis infection among young nursing trainees in South India. PLoS ONE. 2010;5(4):e10408.

66. Gopinath KG, Siddique $\mathrm{S}$, Kirubakaran H, Shanmugam A, Mathai E, Chandy GM. Tuberculosis among healthcare workers in a tertiary-care hospital in South India. J Hosp Infect. 2004;57(4):339-42.

67. Rao KG, Aggarwal AN, Behera D. Tuberculosis among physicians in training. Int J Tuberc Lung Dis. 2004;8(11):1392-4.

68. WHO. India: WHO and UNICEF estimates of immunization coverage: 2019. 2020. https://www. who.int/immunization/monitoring_surveillance/ data/ind.pdf. Accessed 6 Jul 2020.

69. Hatherill M, Scriba TJ, Udwadia ZF, Mullerpattan JB, Hawkridge A, Mahomed H, et al. BCG and new preventive tuberculosis vaccines: implications for healthcare workers. Clin Infect Dis. 2016;62(Suppl 3):S262-7.
70. Dutta AK, Swaminathan S, Abitbol V, Kolhapure S, Sathyanarayanan S. A comprehensive review of meningococcal disease burden in India. Infect Dis Ther. 2020;9(3):537-59.

71. Kulkarni PS, Raut SK, Dhorje SP, Barde PJ, Koli G, Jadhav SS. Diphtheria, tetanus, and pertussis immunity in Indian adults and immunogenicity of td vaccine. ISRN Microbiol. 2011;2011:745868.

72. Goel I, Sharma S, Kashiramka S. Effects of the COVID-19 pandemic in India: an analysis of policy and technological interventions. Health Policy Technol. 2021;10(1):151-64.

73. Dev N, Meena RC, Gupta DK, Gupta N, Sankar J. Risk factors and frequency of COVID-19 among healthcare workers at a tertiary care centre in India: a case-control study. Trans R Soc Trop Med Hyg. 2021;115(5):551-6.

74. Kumar VM, Pandi-Perumal SR, Trakht I, Thyagarajan SP. Strategy for COVID-19 vaccination in India: the country with the second highest population and number of cases. NPJ Vaccines. 2021;6(1):60.

75. Dev K, S KS, Abhay G, Gajanan K, Akash S, Bisure K. Knowledge and awareness of the health care workers about the hepatitis B infection and their vaccination status in a newly started medical college. J Assoc Physicians India. 2018;66(12):27-30.

76. Senthil A, Anandh B, Jayachandran P, Thangavel G, Josephin D, Yamini R, et al. Perception and prevalence of work-related health hazards among health care workers in public health facilities in southern India. Int J Occup Environ Health. 2015;21(1):74-81.

77. Rajoura OP, Roy R, Agarwal P, Kannan AT. A study of the swine flu (H1N1) epidemic among health care providers of a medical college hospital of Delhi. Indian J Community Med. 2011;36(3): 187-90.

78. Raj S, Sharma VL, Singh A, Goel S. The health information seeking behaviour and needs of community health workers in Chandigarh in Northern India. Health Info Libr J. 2015;32(2):143-9.

79. ECDC. Vaccine hesitancy among healthcare workers and their patients in Europe-A qualitative study Stockholm. 2015. https://www.ecdc.europa.eu/ sites/default/files/media/en/publications/ Publications/vaccine-hesitancy-among-healthcareworkers.pdf.

80. Yuan Q, Wang F, Zheng H, Zhang G, Miao N, Sun $\mathrm{X}$, et al. Hepatitis B vaccination coverage among health care workers in China. PLoS ONE. 2019;14(5):e0216598. 